Debreceni Jogi Múhely 2020. (XVII.) 3-4.

Debreceni Egyetem, Állam- és Jogtudományi Kar, Debrecen

(University of Debrecen, Faculty of Law, Debrecen)

DOI 10.24169/DJM/2020/3-4/1

Áron Péter Balogh*

doktorjelölt

Debreceni Egyetem Marton Géza Állam-és Jogtudományi Doktori Iskola

\title{
POSSIBILITIES OF WORKPLACE MEDIATION IN THE EUROPEAN UNION**
}

Debreceni Jogi Múhely, 2020. évi (XVII. évfolyam) 3-4. szám (2020. december 30.)

DOI 10.24169/DJM/2020/3-4/1

Abstract: The world of labor market and industrial relations is a field where conflicts and disputes are inevitable characteristics of the operation, regardless of the form of employment. Also, labor disputes appear both from an individual aspect, where the disputants are the employer and the employee, and in a collective respect, where the disputes take place between the employer(s) and the collective of the workers, typically represented by an employee organization (union) or a works council.

When a conflict or a dispute cannot be resolved through negotiation, the law offers dispute resolution mechanisms for the participants. Therefore, several legal mechanisms have been evolved in order to resolve disputes, starting from the classical form of litigation, where a court determines the end of the dispute by its judgement, and other alternative forms of dispute resolution, such as arbitration, mediation and conciliation, where the parties can reach a decision or a settlement outside of the judicial system of the state.

EU Member States have introduced various legislative rules for labor dispute resolution covering all manner of individual and collective disputes. ADR schemes are also supported by the ILO, as the ILO Recommendation No. 92 (1951) suggests that voluntary conciliation should be made available to assist in the prevention and settlement of industrial disputes between employers and workers. Within the aegis of the European Union, several instruments have emerged with the attempt to elaborate the basic principles for the operation of ADR schemes in the context of cases between businesses and consumers. The Directive 2013/11/EU on alternative dispute resolution for consumer disputes (the "ADR Directive") and Regulation (EU) No 524/2013 on online dispute resolution for consumer disputes (the "ODR Regulation") ensured that consumers could turn to quality alternative dispute resolution entities for all kinds of contractual disputes with traders, and established an EU-wide online platform for consumer disputes that arise from online transactions with traders.

Workplace mediation is widely and successfully utilized in the USA for solely employment purposes both in the private and the public sector. Also, in the United States is a "employment at will" doctrine prevails, that basically means - unless stipulated to the contrary by the parties - the employment relationship can be terminated with immediate effect without any justification (just cause), thus workers do not have access to legal remedies as in the EU where the statutory laws provide a broad protection against arbitrary or unjust termination. Mediation, however, provide an effective solution for employees and workers, even if situated outside the protective scope of labor law.

While the role of customer/consumer ADR and mediation is increasing throughout the whole European

\footnotetext{
* Attorney at Law, PhD Candidate at the University of Debrecen Marton Géza Doctoral School of Legal Studies. (email: arbalogh@gmail.com). Instructor: György Nádas, PhD, associate professor at the University of Debrecen Faculty of Law, Department of Environmental Law and Labor Law.

** Supported by the ÚNKP-19-3-IV-DE-206 New National Excellence Program of the Ministry for Innovation and Technology.
} 
Debreceni Jogi Múhely 2020. (XVII.) 3-4.

Debreceni Egyetem, Állam- és Jogtudományi Kar, Debrecen

(University of Debrecen, Faculty of Law, Debrecen)

DOI 10.24169/DJM/2020/3-4/1

Union, workplace and employment mediation still constitutes a "grey zone". In many of the legal instruments of the EU and also in several products of the national legislations, consumers and workers are treated with the same legal awareness, thus protective laws compensate their weaker position in their legal relationships, but as far as the utilization and access of dispute resolution schemes are concerned, a significant but not always reasonable differentiation can be detected. Also, while mediation is an available tool for individual employment matters, still has not been utilized considerably, and remained an instrument only to resolve mostly collective conflicts. Therefore, the aim of this paper to present various styles of mediations from a comparative perspective, to express their biggest advantages and to highlight the areas where mediation could be more suitable to use in the context of the individual disputes of the workplace.

Keywords: mediation, labour law, employment relationship, EU employment law, ADR

Absztrakt: A munkaerőpiac és a munkaügyi kapcsolatok világa olyan terület, ahol a konfliktusok és viták a múködés elkerülhetetlen „velejárói”, függetlenül a foglalkoztatás formájától. Ezenkívül a munkaügyi viták egyéni és kollektív szempontból is egyaránt megjelennek, ahol egyéni szinten a szemben álló felek a munkáltató és a munkavállaló, kollektív szinten pedig a munkáltató(k) és a munkavállalók csoportja, tipikusan képviselve egy szakszervezet vagy üzemi tanács által.

Ha egy konfliktus vagy vita egyeztetés útján nem oldható fel, a jog vitarendezési mechanizmusokat kínál a résztvevők számára. Ennek okán számos jogi mechanizmus alakult ki a viták rendezésére, kezdve a klasszikus bírósági peres eljárást, amikor is a bíróság itélete állapítja meg a vita eredményét, valamint a vitarendezés más alternatív formáit, például a választottbírósági eljárás, a közvetítés és a békéltetés lehetőségét, ahol a felek képesek döntésre vagy egyeségre jutni az állam rendes igazságszolgáltatási rendszerén kívül.

Az Európai Unió tagállamai különféle szabályokat vezettek be a munkaügyi viták rendezésére, amelyek mindenféle egyéni és kollektív vitára kiterjednek. Az alternatív vitarendezési módszereket a Nemzetközi Munkaügyi Szervezet (ILO) is támogatja. A 92. (1951) számú ILO Ajánlás, kifejezetten azt fogalmazta meg, hogy az önkéntes egyeztetést rendelkezésre kell bocsátani a munkáltatók és a munkavállalók közötti munkaügyi viták megelőzésének és rendezésének elősegítése érdekében. Az Európai Unió égisze alatt számos eszköz alakult ki annak érdekében, hogy kidolgozzák az alternatív vitarendezési rendszerek múködésének alapelveit a vállalkozások és a fogyasztók közötti jogvitákkal összefüggésben. A fogyasztói viták alternatív rendezéséről szóló 2013/11 / EU irányelv („alternatív vitarendezési irányelv”) és az online vitarendezésről szóló 524/2013 / EU rendelet a fogyasztói jogvitákról („,vitarendezési rendelet”) biztosította, hogy a fogyasztók a minőségi alternatív vitarendezési szervezetekhez fordulhassanak különféle fogyasztói/kereskedelmi jogvitáikkal, és létrehoztak egy EU-szintű online platformot is a fogyasztói viták rendezésére.

A munkahelyi közvetítést (mediáció) széles körben és sikeresen alkalmazzák az Egyesült Államokban kizárólag foglalkoztatási célokra, mind a magán, mind az állami szektorban. Megjegyzendő, hogy az Egyesült Államokban az „employment at will” doktrína érvényes, ami alapvetően azt jelenti, hogy a munkaviszony gyakorlatilag bármikor indoklás és azonnali hatállyal felmondható, tehát a munkavállalók hacsak kollektív szerződés vagy munkáltatói szabályzat másként nem rendelkezik - nem férnek hozzá olyan jellegú a jogorvoslatokhoz, mint az EU-ban, ahol a jogszabályok széles körủ védelmet biztostanak az önkényes vagy indokolatlan munkaviszony-megszüntetés ellen. A közvetítés azonban hatékony megoldást kínál a munkavállalók és a munkavállalók számára egyaránt, még akkor is, ha a munkajog védőbástyáin kívül esnek

Míg a fogyasztói alternatív vitarendezés és mediáció szerepe az egész Európai Unióban növekszik, a munkahelyi és a munkaügyi mediáció továbbra is „szürke zónát” képez. Az EU számos jogforrásában, valamint a nemzeti jogi rendszerekben a fogyasztókat és a munkavállalókat azonos figyelemmel veszik számításba, így protektív szabályozással ellensúlyozzák gyengébb és egyensúlyhiányos helyzetüket jogviszonyaikban, a vitarendezési formákhoz való hozzáférés tekintetében jelentős, és nem mindig ésszerü differenciálás mutatható ki. Ugyanakkor, bár a mediáció elérhető eszköz az egyéni munkajogi ügyekben is, jelentősége elhanyagolható, és a legfeljebb csak a kollektív viták megoldására szolgáló jogintézményként 
Debreceni Jogi Múhely 2020. (XVII.) 3-4.

Debreceni Egyetem, Állam- és Jogtudományi Kar, Debrecen

(University of Debrecen, Faculty of Law, Debrecen)

DOI 10.24169/DJM/2020/3-4/1

tekintenek rá. Mindezek okán jelen tanulmány célja, hogy bemutassa és összehasonlítsa a meditáció különféle stílusait, kifejezze azok legnagyobb előnyeit és kiemelje azokat a területeket, ahol a mediáció jobban alkalmazható lehetne a munkahelyi viták során.

Kulcsszavak: mediáció, munkajog, munkaügyi kapcsolatok, munkaviszony, ADR

\section{Introduction}

The world of labour market and industrial relations is a field where conflicts and disputes are inevitable characteristics of the operation. Labor disputes appear both from an individual aspect, where dispute is between the employer and the employee, and in a collective respect, where the disputes take place between the employer(s) and the collective of the workers, typically represented by an employee organization (union) or a works council. When a conflict or a dispute cannot be resolved through negotiation, law offers dispute resolution mechanisms for the participants.

Several legal mechanisms have been evolved in order to resolve disputes, starting from the classical form of litigation, where a court determines the end of the dispute by its judgement, and other types of ADRs, such as arbitration, conciliation and mediation where the parties can reach a decision or a settlement outside the judicial system of the state.

EU Member States have introduced various regulations on dispute resolution schemes that cover all kinds of individual and collective matters. In a few examples, the framework is part of a country's primary legislation on labor standards or the codified law, for example it is included in the Labor Code in Hungary ${ }^{1}$, while other cases, the regulations on dispute resolution varies and can be found scattered in different statutory laws governing labor relations (like in Lithuania or in Slovenia). In other countries, single pieces of legislation are adopted that concern exclusively labor dispute resolution (e.g. Bulgaria, Latvia, Poland). ${ }^{2}$ Although while mediation is an available tool for individual employment matters, still has not been utilized considerably, and remained an instrument only to resolve collective conflicts. Therefore, I would like to present the various styles of mediations, to express their biggest advantages and to highlight the areas where they could be the most suitable to use in employment disputes.

\section{Mediation in general - styles of mediation}

Mediation is an alternative dispute resolution procedure scheme, like arbitration, conciliation and structured negotiation. In mediation, the parties involve a third, neutral party in dispute that is a mediator. It differs from other types of dispute resolution procedures in some significant factors. It is, in general, a voluntary procedure. Mediators usually lack judiciary or legal competence, and as a third party, facilitate for a mutually beneficial solution. While arbitrators are authorized to make decisions that are legally binding, in mediation, the disputants to decide how to move forward in the dispute in order to solve the conflict. While the mediators are not empowered to make decisions concerning the conflict, it is their duty to lead the parties to find a mutually acceptable and voluntarily reached solution, mainly by supporting and facilitating both parties by special negotiation techniques. ${ }^{3}$ Mediation is gaining popularity throughout all over the world. Since its inception, various styles of mediation have been introduced as a technique of conflict resolution. While many slightly different styles can be identified, scholars tend to emphasize these four types: facilitative, evaluative, transformative and narrative.

\footnotetext{
${ }^{1}$ However, the use of ADR techniques is very limited. Mandatory arbitration is prescribed only in two cases. See Article 293 (2) of the Act I of 2012 on the Labor Code of Hungary.

${ }^{2}$ Collective Dispute Resolution through Conciliation, Mediation and Arbitration: European and ILO Perspectives, International Labor Office (ILO), 2007. Accessed at http://www.ilo.org/wcmsp5/groups/public/---europe/---rogeneva/documents/meetingdocument/wcms_366949.pdf on November 15, 2019.

3 STEFFEK, Felix: Mediation in the European Union: An Introduction, p 1. Accessed at https://ejustice.europa.eu/fileDownload.do?id=b3e6a432-440d-4105-b9d5-29a8be95408f on November 15, 2019.
} 
Debreceni Jogi Múhely 2020. (XVII.) 3-4.

Debreceni Egyetem, Állam- és Jogtudományi Kar, Debrecen

(University of Debrecen, Faculty of Law, Debrecen)

DOI 10.24169/DJM/2020/3-4/1

Facilitative mediation developed and has become the most widely used style of mediation, and when most of the mediators were volunteers without the requirement to have any expertise in the area of the dispute concerned. ${ }^{4}$ Facilitative mediator asks questions, and looks for the underlying interests behind the positions occupied by the disputants, and aids the them to find better options for a possible solution. ${ }^{5} \mathrm{~A}$ facilitative mediator has the obligation to be neutral, shall not give any direct advice, recommendations or opinion to the parties, including if the mediation should be successful or the parties instead the matter should proceed to litigation, as it is viewed, the best option shall be negotiated by the parties themselves. Facilitative mediator ensures that the agreement of the parties is concluded based on the complete understanding and acknowledgement of the parties, by holding joint sessions. It is a priority that in this procedure, parties themselves negotiate rather than representatives or solicitors. ${ }^{6}$

The so called 'evaluative' mediation models somewhat a judicial settlement conference while shoving relative similarities with a jointly appointed arbitrator. Evaluative mediation suggests that both parties can rely on the guidance of an expert, a professional and objective person. The evaluative mediator - opposed to the facilitative mediator - intervenes in the mediation more extensively, also often formulates recommendations or provides legal opinions to the extent as to what might occur if the parties opted for litigation later on, but also whether they should choose litigation instead of mediation. Concludingly, the evaluative mediator - also from a professional perspective - considers the parties' legal rights from a professional perspective rather than focusing on the satisfaction of the individual interests. During evaluative mediation, the mediator shall invests considerable time to highlight the weaknesses of each side and to highlight the possible costs of pursuing litigation. ${ }^{7}$ Evaluative mediation is often used when the dispute concerns financial matters. The evaluative mediator is required to have (especially legal) expertise to provide a professional opinion to the parties. This evaluation can e.g. reflect on the legal issues or factual concerns based on the background of the case, can be financial, engineering related, etc. The evaluative mediator shall also present the strengths and/or weaknesses of the parties to each other. One of the unique elements of the evaluative mediators is the mediator's proposal, where the mediator evaluates the case and suggests an estimated (pecuniary) settlement proposal to the parties. Parties are requested to reject or accept the offer proposed by the mediator under the exact terms, so no modification or amendment shall be made. Mediator's proposal is strictly confidential so it is prohibited to disclose the responses he or she received, unless both parties accept the offer. ${ }^{8}$

Transformative and narrative styles of mediation are considered "newer". The transformative model stresses the transformation of the dialogue that matters the most to the disputing parties, rather than to settle. ${ }^{9}$ The goal of the mediator is to assist the parties identify opportunities with special techniques, such as empowerment, mirroring, acknowledgement and recognition as the mediator gets more and more involved in the dialogue. It is the choice of the mediator how to act and direct the conversation during the sessions, and thus to change the direction of the communication. In transformative mediation, reaching

\footnotetext{
${ }^{4}$ EXON, Susan Nauss: The Effects that Mediator Styles Impose on Neutrality and Impartiality Requirements of Mediation. University of San Francisco Law Review, 2008, Volume 42 Issue 3 , Article 1., pp 577-620.

Accessed at https://repository.usfca.edu/usflawreview/vol42/iss3/1 on November 15, 2019.

5 ZuMETA, Zena, Styles of Mediation: Facilitative, Evaluative, and Transformative Mediation, 2018. Accessed at http://www.mediate.com/articles/zumeta.cfm on November 15, 2019.

${ }^{6}$ CHERN, Cyril: The commercial mediator's handbook. InformaLaw, 2014, p. 16.

${ }^{7}$ LEvin, Murray S.: The Propriety of Evaluative Mediation: Concerns About the Nature and Quality of an Evaluative Opinion, Ohio State Journal on Dispute Resolution, 2001, Volume 16 Issue 2., p. 269.

https://kb.osu.edu/dspace/bitstream/handle/1811/80085/OSJDR_V16N2_267.pdf?sequence=1

${ }^{8}$ Hochman, Stephen A.: A Mediator's Proposal - Whether, When and How It Should Be Used? 2010. Accessed at http://www.mediate.com/pdf/mediatorsproposal.pdf on November 15, 2019.

${ }^{9}$ FOLGER, Joseph - BUSH, Robert A. Baruch: The promise of mediation: the transformative approach to conflict. (2nd reviewed edition), San Francisco, CA, USA, Jossey-Bass, 2004, pp. 224-226; FolGER, Joseph and BusH, Robert A. Baruch: Transformative Mediation, International Journal of Conflict Engagement and Resolution. 2014. Accessed at: https://scholarlycommons.law.hofstra.edu/faculty_scholarship/441; SOLER Salvador Garrido: Insight mediation: a reflective and pedagogical model to address conflicts, Mediación insight: un modelo reflexivo y pedagógico para abordar los conflictos. Revista de Mediación, 2017, Vol. 10 Issue 10, pp. 1-9. Accessed at https://revistademediacion.com/wpcontent/uploads/2018/01/Revista20-en-e10.pdf on November 15, 2019.
} 
Debreceni Jogi Múhely 2020. (XVII.) 3-4.

Debreceni Egyetem, Állam- és Jogtudományi Kar, Debrecen

(University of Debrecen, Faculty of Law, Debrecen)

DOI 10.24169/DJM/2020/3-4/1

the settlement may not be considered as the sign of success. The highlight of the mediation shifts to the personal empowerment, interpersonal recognition, and to facilitate a constructive interaction. ${ }^{10}$

The fourth style of mediation is narrative mediation. It shows several features of narrative therapy. A narrative mediator asks the parties to view the conflict as an outsider, through telling a story from third person. It suggests that people see themselves as being bound to the conflict cycle. ${ }^{11}$ After the storytelling is finished, parties cooperate with the mediator to create a new story, where the conflict is resolved and the story leads to a settlement. It is aimed to detach the parties from the tensions and to protect the underlying relationship during and after the mediation. ${ }^{12}$

The characteristics of the different resolution techniques, shall be considered while choosing the resolution procedures. The amount of intervention provided to the mediator, the flexibility of the procedure, confidentiality, enforceability, impact on the relationship with the party in conflict, sustainability of the conflict resolution, material quality of the solution, duration of the procedure, direct and indirect procedure costs differs by each type of mediation. Also, the impact of the mediation shall be interpreted not only from legal, but from financial, personal, even psychological aspect. Concludingly, mediation can be more quick and cost-efficient form of dispute resolution, than litigation that although does not produce a judgment, but seeks mutual satisfaction and a voluntary solution that is acceptable to all the parties involved. ${ }^{13}$

\section{Labor and employment mediation}

An effective conflict resolution scheme is essential for a well-functioning labor market, as labor relations inevitably include labor disputes. Effective conflict-resolution is also a sign of the efficient and equitable industrial relations system. Generally speaking, there are two categories of labor and employment disputes: individual and collective disputes. Individual disputes concern individual worker (employee) and an employer, while collective (labor) disputes are between a group of workers, usually represented by a trade union, and the employer(s) or an employer organization. ${ }^{14}$ Collective disputes can further be broken down to two types: the so called rights disputes and interest disputes. Rights disputes concern the implementation, interpretation or application of the (statutory) law, or the regulations of an applicable collective agreement, while interest dispute involve disagreements over the determination, modification of the rights. Interest disputes usually emerge when bargaining takes place, if a collective agreement does not apply or when it is being re-negotiated. ${ }^{15}$ Rights disputes are based on laws or agreements, are adjudicable,

${ }^{10}$ ZumeTA, Zena, op. cit.; BuSH, Robert A. Baruch - PoPE, Sally Ganong: Changing the Quality of Conflict Interaction: The Principles and Practice of Transformative Mediation, Pepperdine Dispute Resolution Law Journal, 2002, Vol. 1. Issue 3, p. 84.

${ }^{11}$ Winslade, Jour - MonK, Gerald. Narrative Mediation. A new approach to conflict resolution. Jossey-Bass, 2000 , p. 8.

12 HANSEN, Toran, The Narrative Approach to Mediation. 2003. Accessed at http://www.mediate.com/articles/hansent.cfm on November 15, 2019.

13 SteffeK, op. cit. p 4.; Foster, Katina: A Study in Mediation Styles: A Comparative Analysis of Evaluative and Transformative Styles. 2003. Accessed at http://www.mediate.com/articles/fosterk1.cfm on November 15, 2019.

${ }^{14}$ It is worth noting that labor dispute is also possible if the workers are not represented by a union. In Hungary, for example, labor dispute is possible with a works council or even - in some cases - non-organized workers represent themselves as a group/collective in a dispute. It is essential, considering, that union representation is showing a declining figure worldwide. To express my perspective on these topics in details would exceed the limits of this study, but I have presented my view on this in a few articles already. See: BALOGH, Aron Peter: Issues of Collective Autonomy - Who Shall Represent the Workers? In: Revista Facultății de Drept Oradea - The Journal of the Faculty of Law Oradea, Pro Universitaria, Bucuresti. Vol 2. Issue No. 2. 2019, pp. 9-19. BALOGH, Aron Peter: A Comparative Overview of the Collective Contractual Capacity of Labour Unions in Hungary, In: Marcel Szabó, Petra Lea Láncos, Réka Varga (edt.), Hungarian Yearbook of International Law and European Law 2017, Hague, Eleven International Publishing, 2018. pp. 513-526. BAlogh, Aron Peter: The Possible Role of The Trade Unions and their Collective Bargaining Agreements in the USA in the 21th Century, In: Szabó Miklós (edt.), Doktoranduszok Fóruma Miskolc, Miskolci Egyetem, 2017. pp. 27-31.

${ }^{15}$ Collective Dispute Resolution through Conciliation, Mediation and Arbitration: European and ILO Perspectives, International Labor Office (ILO) (2007), op. cit. 
Debreceni Jogi Múhely 2020. (XVII.) 3-4.

Debreceni Egyetem, Állam- és Jogtudományi Kar, Debrecen

(University of Debrecen, Faculty of Law, Debrecen)

DOI 10.24169/DJM/2020/3-4/1

with suitable quasi-judicial adjustment machinery. Interest disputes, however, while non-adjudicable, may or may not be arbitrable. ${ }^{16}$

Mediation could be a useful instrument in individual employment disputes as well. The informal approach it utilizes may provide a greater flexibility to adjust to specific circumstances. The confidentiality of the process provides a chance for an open and honest conversation. Mediation may also provide quick response to tensions and can shut down potentially damaging disputes. It reduces the extent of grievances, and it is far cheaper compared to litigation, that may cause imminent expenditures to employer or the employee, as well as additional inconvenient burdens. Moreover, litigation is unable to resolve systemic problems at the workplace that may underlie in an individual dispute. The employer is more likely to get to the root of the problem in mediation, therefore it enables to introduce changes to workplace practices, and both parties can earn long term benefits. ${ }^{17}$

Differentiation is made between workplace mediation and employment mediation. On the one hand, workplace mediation usually concerns conflicts of general work relationships and work arrangements, rather than rights. The process focuses on the existing relationship, strives to avoid the escalation of the conflict to re-create a sensible conversation between the disputants, aids them find lasting resolution by agreement and provides an opportunity to restore the relationship. On the other hand, employment mediation always refers to a process where the dispute concerns the legal rights related to the employment. Therefore, attorneys are often engaged, and the mediation process offers a safe and positive environment compared to a court. It focuses on providing a settlement acceptable for both parties, at the same time saving time and money. It also prevents the loss of reputation, the potentially negative consequences and distractions of litigation. In both types, the role of the mediator is to assist the better understanding of the concerns and interests of the parties. As it can be inferred, facilitative mediation is the dominant style of workplace and employment mediations. It has to be highlighted however, that there is an ongoing debate in literature, how intensively the mediators should intervene, evaluate the case, suggest solutions (see the description of the styles above), or formulate an opinion that are not particularly the roles of a classic facilitative mediator. This is especially true in workplace disputes where parties may occupy unbalanced positions, exercise different levels of powers, authorities or rights and the preservation of the relationship is fundamental. ${ }^{18}$

Two types of mediators intervene to help resolve disputes in the employment and at the workplace: internal and external. External mediators are experts outside of the company, often with experience in mediating various types of disputes. Who facilitate and mediate disputes in order to reach a settlement. Internal mediators are either internal experts dedicated to handle disputes within the enterprise, or a nominated person within the organization, such as a member of the HR, who is sought in case there is a disagreement between (at least) two employees. ${ }^{19}$ Using internal or external mediators both have their own different benefits. Using an internal mediator ensures a more informal environment that is easier and faster to set up and to access for the staff, the mediator has more knowledge of the organizational background, and could have a higher emphasis on joint meetings. The pure advantage of external mediation is its neutrality, although it provides a much more formal approach, because the mediator has

\footnotetext{
${ }^{16}$ SpIelmans, John V.: Labor Disputes on Rights and on Interests. The American Economic Review, Vol. 29, No. 2, pp. 299-312 Published by: American Economic Association, 1939. Accessed at http://www.jstor.org/stable/1803627 on November 15, 2019.

17 PODro, Sarah - SUFF, Rachel: Mediation: an approach to resolving workplace issues. ACAS, 2013. Accessed at https://www.acas.org.uk/media/949/Mediation-An-approach-to-resolving-workplace-issues/pdf/Mediation-anapproach-to-resolving-workplace-issues.pdf on November 15, 2019.

18 Bollen Katalien - EuWEMA. Martin - MunduATE. Lourdes: Promoting Effective Workplace Mediation. In: BoLLEN, Katalien (ed.): Advancing Workplace Mediation Through Integration of Theory and Practice, Springer, 2016 , p. 2.

19 The typical example for this is the ombudsman mediation at several universities. Ombudsman offices at universities as permanent conflict mediation agencies, were first established in Canada and in the USA as a governmental policy to reduce the quickly escalating on- campus conflicts of the anti-Vietnam War and the pacifist movements, later in Mexico, the post-Franco Spain (the first one in a European country, and in Germany and Austria. See: LeIDEnfrost, Josef (2015): Conflict resolution at universities: Ombudsman mediation as a tool? Perspective/Focus, 2015, Issue 1, pp. 101-106.
} 
Debreceni Jogi Múhely 2020. (XVII.) 3-4.

Debreceni Egyetem, Állam- és Jogtudományi Kar, Debrecen

(University of Debrecen, Faculty of Law, Debrecen)

DOI 10.24169/DJM/2020/3-4/1

no knowledge of the organizational culture and the parties. But the external mediator gives an objective perspective to the process, considering that the mediator had wider experience on various organizational conflicts. ${ }^{20}$ In mandatory mediation parties are obliged to engage into the process, while the voluntariness provide the parties to control, even to terminate the process as they wish. While the continuing of the participation is never mandatory, 'good faith' participation is prescribed in several laws and regulations. ${ }^{21}$

\section{Workplace mediation in the USA}

Dispute resolution at the workplace has a troubled history in the USA since the early days of unionization, such as the federal governmental intervention to regulate working conditions. Since then, dispute resolution improved under collective bargaining and evolved outside the judiciary system. In the past 150 years collective agreements negotiated to improve working conditions and labor standards, including the enforcement of the collective agreements through alternative internal grievance procedures, finally resulting in the rise of the significance of arbitration. The judiciary did not recognize written arbitral awards as binding to the parties until 1960. While by 1940, only 10 per cent of the CBAs provided voluntary arbitration over issues of contract application and interpretation, a decade later, almost all of the collective agreements contained arbitration clauses. Later on, the Supreme Court recognized the decisions of arbitrators as binding to the parties in its Steelworkers' Decisions. While in Europe labor courts resolve labor disputes, in the US it became the authority of unions and the employers to utilize ADR mechanisms to resolve their differences. Beside arbitration, mediation of interest disputes has a growing importance, regarding the content of new collective bargaining agreements, and arbitration is provided for the interpretation and application of such agreements. ${ }^{22}$

It shall also be highlighted that in United States the doctrine "employment at will" prevails. Unless stated otherwise by law, the employment relationship can be terminated with immediate effect without any justification (just cause). Therefore, legal protection against unlawful termination restricted to the just cause protections that is provided to employees governed by collective agreements or the protective provisions of the employment contracts. The only legal remedy against discharge in the non-union sector in the United States is based upon the proven violation of certain statutory law. ${ }^{23}$ Workers in the United States do not have access legal remedies in the present and are unlikely to do so in the future, in contrast with e.g. countries of the Europe, where the employment tribunals provide a broad protection against wrongful discharge and termination, also, severance pay and notice period is provided. It is most likely that this factor has a huge impact on the popularity of ADR, especially mediation in employment and labor disputes in the United States. ${ }^{24}$

20 Model Mediation Clauses and Mediation in Employment Policies, CEDR, 2016. Accessed at https://www.cedr.com/about_us/modeldocs/?id=19 on November 15, 2019.

${ }^{21}$ SuCH, Virginia Vilches - VerbeKe, Alain Laurent - MENKEL-MEAdow, Carrie: Mandatory Workplace Mediation in Advancing Workplace Mediation Through Integration of Theory and Practice. Springer, 2016, pp. 145-170.

22 Dunlop, John T. - ZACK, Arnold M.: Mediation of Employment Disputes, accessed at http://www.law.harvard.edu/programs/lwp/people/staffPapers/zack/MEDIATION\%20OF\%20EMPLOYMEN T\%20DISPUTES\%20dunlop\%20and\%20zack.pdf on January 1, 2017.

${ }^{23}$ Such as termination for seeking to invoke statutory rights under Occupational Safety and Health Act of 1970 (OSHA) or Labor Management Relations Act of 1947 (LMRA) or even under certain whistleblower statutes or for violation of statutory prohibitions against employee discrimination such as under Title VII of the Civil Rights Act of 1964, Americans with Disabilities Act of 1991 (ADA), constructive discharge - where the employer wrongfully makes working conditions so intolerable that the employee is forced to resign, etc.

${ }^{24}$ For example. both in the railway and traffic industry labor conflicts has a $97 \%$ success rate and have been settled peacefully in the United States. See in ZAHORKA Hans-Juergen, Mediation in Labour Relations: "What can be learned from the North American and EU Example? Labour Legislation and Arbitration Project, Annex 5, accessed at http://www.libertas-institut.com/de/PDF/Mediation.pdf on November 15, 2019. 
Debreceni Jogi Múhely 2020. (XVII.) 3-4.

Debreceni Egyetem, Állam- és Jogtudományi Kar, Debrecen

(University of Debrecen, Faculty of Law, Debrecen)

DOI 10.24169/DJM/2020/3-4/1

\section{Promotion of labor and employment ADR schemes}

ILO Recommendation No. 92 (1951) on the Voluntary Conciliation and Arbitration Recommendation is the main ILO instrument that concerns alternative dispute resolution schemes. It has to be noted, however, that it does not include mediation as a possible way dispute management. It is suggested by the convention that voluntary conciliation "should be made available to assist in the prevention and settlement of industrial disputes between employers and workers." Equal representation of employers and workers is also recommended, and it suggests the procedures should be free and expeditious, parties shall be provided the opportunity to engage in conciliation either voluntarily, and only as an exception by the order of the authority. Without limiting the right to collective action, it also suggests to refrain from strikes while conciliation or arbitration procedures are in progress, or a CBA is in force. Article 5 paragraph (2) (e) of the ILO Convention No. 154 (1981) on Collective Bargaining, expressly states that the establishment of bodies and procedures to resolve labor disputes should contribute to the promotion of collective bargaining. Although Convention No. 154 focuses on collective bargaining, it provides the voluntary use of alternative dispute resolutions as part of the bargaining process (Article 6). It is explicitly the objective of ADR mechanisms in collective labor as well to provide mutually beneficial solutions for employees and employers and, to promote collective bargaining through bipartite negotiation.

As far as the public sector is concerned, ILO Convention No. 151 (1978) on Labor Relations (Public Service) explicitly includes mediation as an instrument to resolve labor disputes, and provides that the conditions of employment are to be sought "through independent and impartial machinery, such as mediation, conciliation and arbitration, established in such a manner as to ensure the confidence of the parties involved". 25 Also, the ILO Recommendation No. 130, (1967) on Examination of Grievances views dispute resolution from the perspective of the enterprise level that involves disputes over the breach of CBAs. The instrument provides several recommendations on the development and implementation of workplace dispute resolution schemes, highlighting the importance of preventative instruments and measures, such as adequate executive policy, also by emphasizing the importance of the co-operation between the social partners on decisions that may affect the employees. It also suggests that even if the dispute has not been resolved, the opportunity for a final settlement offer shall be provided by either through the procedures provided by collective agreement, e.g. through conciliation, arbitration, or through any other judicial procedure, (Article 17). In recommendation No. 158, (1978) on Labor Administration the role of the public administration in resolving disputes is highlighted. It suggests that the "competent bodies within the system of labor administration should be in a position to provide, in agreement with the employers' and workers' organizations concerned, conciliation and mediation facilities, appropriate to national conditions, in case of collective disputes". ${ }^{26}$

\section{Mediation in the European Union (EU)}

In Europe, the need to promote alternative dispute resolutions in order to decrease litigation and to decrease the expenditures of court proceedings was recognized well belated compared to the USA. Recommendation of the Committee of Ministers of the Council of Europe encouraged countries to incorporate mediation in their legal systems, was adopted on September 18, 2002, that The trend intensified the trend. Later, in 2004, the Directorate of Justice and Home Affairs of the European Commission adopted a document called: The Code of Conduct for European Mediation Services. It constituted a legislation proposal to ensure uniform practices and standards in the EU. This was followed by the Directive 2008/52/EC of the European Parliament and of the Council of Certain Aspects of Mediation on Civil and Commercial Matters (Mediation Directive) that provided a framework for crossborder mediation, and gave a binding effect to the earlier Recommendations. The Directive required the European member states to implement the necessary provisions on cross-border mediation until May 20, 2011. Later, the European Parliament enacted a Resolution that concerned the implementation and the

\footnotetext{
25 Article 8, ILO Convention No. 151 (1978)

${ }^{26}$ Collective Dispute Resolution through Conciliation, Mediation and Arbitration: European and ILO Perspectives, op. cit. p. 7-10.
} 
Debreceni Jogi Múhely 2020. (XVII.) 3-4.

Debreceni Egyetem, Állam- és Jogtudományi Kar, Debrecen

(University of Debrecen, Faculty of Law, Debrecen)

DOI 10.24169/DJM/2020/3-4/1

application of the 2008 Directive (2011/2026 (INI)) and imposed the obligation on the Member States to regulate mediation in their own systems. ${ }^{27}$

In 2016, the Commission issued a report on the application of the Mediation Directive. Its evaluation shown overall the rising awareness of the Member States, and by the advantages of mediation, the implementation of the Mediation Directive has had a significant impact on the legislations of the Member States. Fifteen Member States had already introduced a comprehensive mediation system in place prior to the adoption of the Directive, therefore it brought no changes to their system. Nine Member States, however, either had scattered regulations on mediation, it was based on self-regulation, especially in the private sector. Substantive and comprehensive changes have been triggered by the adoption of the Directive on existing mediation framework, for example, in four of the Member States, legislative frameworks regulations on mediation were adopted for the first time. The report also identified certain difficulties concerning the operation of the national mediation systems. These include for example the lack of mediation "culture" in most of the Member States, insufficient experience, knowledge and expertise on how to handle cross-border issues, the low level of awareness of mediation and the functioning of the quality control mechanisms for mediators. In the public consultation respondents highlighted the lack of sufficient knowledge on mediation, and that a "cultural change" was still necessary to ensure trust in this process. It has also been stressed that judges shown unwillingness to introduce mediation as an option to the parties. ${ }^{28}$ Concludingly, while appropriate legislation have been adopted by most European countries, it does not necessarily resulted in a broader understanding of mediation, e.g. as a method that is comfortably suggested for an efficient conflict resolution. Moreover, even if such a is made by a party, it may not be fully understood by the other side due to limited knowledge on the process.

As I previously introduced, the application of mediation to (collective) labor is provided by international conventions, but an instrument generally dealing with labor and/or employment dispute resolution has not yet been introduced on an EU level. It has to be noted, workplace mediation has a very limited regulation in the European Union. Some argue that the EU Mediation Directive cannot be applied in employment matter is concerned for the following reasons: First, employment or workplace mediation is not mentioned specifically in the Directive, neither in the title nor within the text, as the Directive only concerns a civil or commercial matters. Moreover, the Directive explicitly prescribes that it shall not apply to rights and obligations on which the parties are not free to decide the relevant and applicable law, such as employment law. It has to be noted however, that some consider that the Directive should be applied in labor matters where party negotiation is provided. For example, parties are free to mediate on issues like overtime, as long as mandatory legal regulations are met. The main argument supporting this idea expresses that (in some Member States) labor and employment law is the integral part of Civil Law, as employment disputes are solved by civil courts. Second, labor and employment issues - regardless of the first argument - are already included in other regulatory instruments of the EU in civil and commercial matters. Also, the European Union has demonstrated its interest in setting up an international mediation system for cross-border employment disputes. In 2003, the EC issued a study on "Conciliation, Mediation and Arbitration in the States of the European Union" on the field of collective labor disputes to address the possibilities of ADR for collective disputes. One of its main findings was that great differences can be identified between national labor law regulations, and a wide range of mediation processes can be found in in each country foe workplace disputes. ${ }^{29} 30$

\footnotetext{
27 ZAHORKA, op. cit., pp. 8-9.; RENWALD, Roman: Mediation in Europe: the most misunderstood method of alternative dispute resolution. World Arbitration Report, 2014, p. 14-20. Accessed at http://www.weil.com/ /media/files/pdfs/WWAR_Newsletter_Spring2014.pdf on November 15, 2019.

${ }_{28}$ Report from the Commission to the European Parliament, the Council and the European Economic and Social Committee on the application of Directive 2008/52/EC of the European Parliament and of the Council on certain aspects of mediation in civil and commercial matters, p. 11-12. Accessed at https://eur-lex.europa.eu/legalcontent/EN/TXT/PDF/?uri=CELEX:52016DC0542\&from=EN on November 15, 2019.

${ }^{29}$ SUCH - VERBEKE - MENKEL-MEADOW, op. cit., p. 156.

${ }^{30}$ Grand, Barbara, Mediation to Enforce Labour Rights: How Far can the European Model for ADR be Beneficial on Employment Dispute. Global Journal of Management and Business Research, 2014, Volume 14, Issue 3, pp. 37-47.
} 
Debreceni Jogi Múhely 2020. (XVII.) 3-4.

Debreceni Egyetem, Állam- és Jogtudományi Kar, Debrecen

(University of Debrecen, Faculty of Law, Debrecen)

DOI 10.24169/DJM/2020/3-4/1

\section{Conclusions and observations}

As it can be inferred from above, neither of the instruments of the European Union explicitly prohibits mediation as the tool of resolving employment and workplace disputes, but they do not promote it either. However, the Commission emphasized in its Report on the Mediation Directive that compulsory/mandatory mediation, that is prescribing compulsory mediation in a few instances, such as commercial, family, employment law matters or claims that concern small amount affects the exercise of the right to an effective remedy before a tribunal as enshrined in Article 47 of the Charter of Fundamental Rights of the European Union. Although a majority of the stakeholders were in favour of a more compulsory and direct approach towards mediation, the Member States and academics were in opposition. ${ }^{31}$ It also has to be highlighted, that in some member states, workplace and employment mediation has already been an existing instrument. For example, in the Netherlands, according to the Annual Report for the Council for the Judiciary of 2010, 5\% of the cases resolved through mediation were labor/employment dismissal cases, but in administrative law, the second highest number of disputes were related to labor law cases (25\%), In 2011, however, labor or employment dispute constituted $25 \%$ of the total disputes handled by the National Mediation Institute. Furthermore, the NMI issued a short questionnaire in 2011 to all registered mediators seeking information about cross-border mediations, which show that $22 \%$ of the total number of cross-border mediation cases concerned labor law matters (commercial law was only 19\%). ${ }^{32}$ It can also be inferred from the research that there is an increased use of extra-judicial mechanisms, especially mediation, for resolving disputes, particularly with respect to ecommerce.

Within the European Union, several instruments have emerged that attempted to elaborate the basic regulations for the establishment of ADR schemes in the context of cases between businesses and consumers. The Directive 2013/11/EU on alternative dispute resolution for consumer disputes (the "ADR Directive") and Regulation (EU) No 524/2013 on online dispute resolution for consumer disputes (the "ODR Regulation") provided consumers to access alternative dispute resolution organizations in all sort of civil matters in commercial matters, and established an online platform for consumer disputes that arise from e-commerce. These instruments also encouraged the Member States to set up platforms for consumers. Member States were required to transpose the Directive into national law by 9 July 2015. The ODR Regulation come into force straight after within half year, on 9 January 2016 (although some Member State obligations, e.g. to set up a national ODR contact point was applied also from 9 July 2015). The Regulation also imposed obligations on Member States, its authorities, certified ADR providers, and businesses engaged in commerce with consumers. To ensure that ADR is provided by a certified body was a fundamental obligation to the Member states for all disputes and complaints that concerns consumers..$^{33}$

While the role of customer/consumer ADR and mediation is increasing throughout the whole European Union, workplace and employment mediation still constitutes a "grey zone" within the EU. In many of the legal instruments of the EU and also in several products of the national legislations, the consumers, and workers are treated with the same awareness, and protective laws compensate their weaker position. The weakness of the individual consumer is a result of his/her indirect relationship with the producer, especially when purchasing on the internet, of his/her limited knowledge and hidden risks and imperfections of the particular product or service. On the other hand, the law provides protection for the individual consumer, presuming that the business entity has many obligations and diligence regarding the applicable consumer/customer laws. It also has to be remarked that a business entity may have better opportunities to afford effective legal service, whereas the customer e.g. likely does not have a permanent

\footnotetext{
31 Report from the Commission to the European Parliament, p. 9.

32 DE PaOlo, Giuseppe (ed.): Rebooting' the Mediation Directive: Assessing the Limited Impact of its Implementation and Proposing Measures to Increase the Number of Mediations in the EU. European Parliament's Committee on Legal Affairs. 2014. Accessed at http://www.europarl.europa.eu/thinktank/en/document.html?reference=IPOLJURI_ET(2014)493042 on November 15, 2019.

33 O'NEILL, Jan: UK Government announces plans for implementation of the EU ADR Directive and ODR Regulation. 2015. Accessed at http://hsfnotes.com/adr/2015/01/05/uk-government-announces-plans-for-implementation-of-the-euadr-directive-and-odr-regulation/ on November 15, 2019.
} 
Debreceni Jogi Múhely 2020. (XVII.) 3-4.

Debreceni Egyetem, Állam- és Jogtudományi Kar, Debrecen

(University of Debrecen, Faculty of Law, Debrecen)

DOI 10.24169/DJM/2020/3-4/1

attorney. Similarly, to the consumer, the employees also have an unbalanced position when a dispute emerges against the employer. The employer also constitutes a business entity, presumably having a more financial power and legal awareness provided by its attorneys, when facing a single employee. ${ }^{34}$ Other aspect of this issue could be that after almost 20 years in the 21th century, labor and employment is going through huge changes. In particular, various forms of work have been evolved while people who perform may fall outside the protective scope of labor law while engaging into any kind of relationship of employment (e.g. independent contractor, personal service contract, commercial agent etc.). Still, while the consumer ADR is increasing and both the consumer and the businesses benefit from the services it can provide, workplace mediation is an extraordinary tool of dispute resolution throughout the European Union.

Mediation - especially facilitative and transformative mediation - is an informal, simply structured process. There are no strict procedural rules governing mediation. In the spirit of neutrality, the mediator is obliged to withhold his or her own legal or personal opinion on the resolution, contrary to arbitration, conciliation, or litigation, where, for example, the arbitrator makes a distinct judgment, the court provides a legal guidance, or issues an order. Mediators, unlike judges and arbitrators, are provided the opportunity to meet with the parties personally, to analyse the position of the parties with properly addressed questions. A mediator could be particularly useful in negotiations, and could mean the difference for a successful resolution, providing much more than a single business negotiation. Mediation is no place for discovery - any statement that was presented within the intent of compromise shall not be utilized by the parties in any subsequent litigation if mediation has not been successful, and litigation ensues. The goal of the mediator is to engage the parties into a conversation that lets them gain a full understanding of their issues and interests, to generate possible alternatives, and to them decide how to move forward. As a result of mediation, the parties might reach a voluntary agreement that could reasonably end the conflict, but this is just one possible outcome. Even if the parties will not reach a voluntary and mutually benefiting agreement, mediation would help them to focus on the unresolved issues and help them understand their conflict better, as mediation is a cheaper and quicker and more effective way of resolution than any other, also, it supports the preservation of relationships between the disputing sides. Its open and flexible style, its friendly tone can be is valuable in issues concerning only minor dispute arises in the course of a longstanding relationship - like the employment relationship..$^{35}$ Under these conditions and circumstances, I do not see any contrary argument or any obstacle why the parties should not - at least - try to resolve their differences in front of a mediator when a workplace/employment conflict emerges. I also truly believe that the future lies in mediation for the European labor and employment disputes. ${ }^{36}$

\section{Bibliography}

BOLLEN Katalien - EUWEMA. Martin - MUNDUATE. Lourdes: Promoting Effective Workplace Mediation. In: BOLLEN, Katalien (ed.): Advancing Workplace Mediation Through Integration of Theory and Practice. Springer, 2016, pp. 1-17. https://doi.org/10.1007/978-3-319-42842-0_1

BUSH, Robert A. Baruch - POPE, Sally Ganong: Changing the Quality of Conflict Interaction: The Principles and Practice of Transformative Mediation. Pepperdine Dispute Resolution Law Journal, 2002, Vol. 1. Issue 3, pp. 67-96.

CHERN, Cyril: The commercial mediator's handbook. InformaLaw, 2014, 408 pages

\footnotetext{
34 GRANDI, op. cit., p. 45.

${ }^{35}$ Leidenfrost emphasized this approach regarding ombudsman mediation: "[...] there is a growing trend - especially in the USA - to "economise" conflicts, i.e. to perform cost-benefit calculations, and consequently to increase institutionalised conflict prevention." LEIDENFROST, op. cit., p. 106.

36 Renwald clearly states that mediation is completely misunderstood in Europe. He states that: "[m]any judges and attorneys do not confidently promote mediation because of a widespread uncertainty as to how mediation works in practice. The most common mistake in understanding mediation arises from the fact that a lot of professionals associate mediation with arbitration. This means that people do not distinguish between the ambience of a mediation, where the mediator is withholding his or her own opinion on the resolution, with that of an arbitration, where the arbitrator makes a distinct judgment. Instead, the job of the mediator is to bring the parties to a common resolution, mostly by posing well formulated questions." - see RENWALD, op. cit., p. 18.
} 
Debreceni Jogi Múhely 2020. (XVII.) 3-4.

Debreceni Egyetem, Állam- és Jogtudományi Kar, Debrecen

(University of Debrecen, Faculty of Law, Debrecen)

DOI 10.24169/DJM/2020/3-4/1

https://doi.org/10.4324/9781315767444

Collective Dispute Resolution through Conciliation, Mediation and Arbitration: European and ILO

Perspectives, International Labor Office (ILO), 2007. Accessed at http://www.ilo.org/wcmsp5/groups/public/---europe/---ro-

geneva/documents/meetingdocument/wcms_366949.pdf on November 15, 2019.

DE PAOLO, Giuseppe (ed.):Rebooting' the Mediation Directive: Assessing the Limited Impact of its Implementation and Proposing Measures to Increase the Number of Mediations in the EU. European Parliament's Committee on Legal Affairs. 2014. Accessed at http://www.europarl.europa.eu/thinktank/en/document.html?reference=IPOL-JURI_ET(2014)493042 on November 15, 2019.

DUNLOP, John T. - ZACK, Arnold M.: Mediation of Employment Disputes, accessed at http://www.law.harvard.edu/programs/lwp/people/staffPapers/zack/MEDIATION\%20OF\%20EMPL OYMENT\%20DISPUTES\%20dunlop\%20and\%20zack.pdf on January 1, 2017

EXON, Susan Nauss: The Effects that Mediator Styles Impose on Neutrality and Impartiality Requirements of Mediation. University of San Francisco Law Review, 2008, Volume 42 Issue 3, Article 1., pp 577-620.

FOLGER, Joseph - BUSH, Robert A. Baruch: The promise of mediation: the transformative approach to conflict. (2nd reviewed edition), San Francisco, CA, USA, 2004, Jossey-Bass, pp. 224-226;

FOLGER, Joseph - BUSH, Robert A. Baruch: Transformative Mediation. International Journal of Conflict Engagement and Resolution. 2014. Accessed at: https://scholarlycommons.law.hofstra.edu/faculty_scholarship/441;

FOSTER, Katina: A Study in Mediation Styles: A Comparative Analysis of Evaluative and Transformative Styles. 2003. Accessed at http://www.mediate.com/articles/fosterk1.cfm on November 15, 2019.

GRANDI, Barbara, Mediation to Enforce Labour Rights: How Far can the European Model for ADR be Beneficial on Employment Dispute, Global Journal of Management and Business Research, 2014, Volume 14, Issue 3, pp. 37-47

HANSEN, Toran: The Narrative Approach to Mediation. 2003. Accessed at http://www.mediate.com/articles/hansent.cfm on November 15, 2019.

HOCHMAN, Stephen A., A Mediator's Proposal - Whether, When and How It Should Be Used? 2010, Accessed at http://www.mediate.com/pdf/mediatorsproposal.pdf on November 15, 2019.

LEIDENFROST, Josef: Conflict resolution at universities: Ombudsman mediation as a tool? Perspective/Focus. 2015, Issue 1., pp. 101-106.

LEVIN, Murray S.: The Propriety of Evaluative Mediation: Concerns About the Nature and Quality of an Evaluative Opinion, Ohio State Journal on Dispute Resolution. 2001, Volume 16 Issue 2., p 269.

Model Mediation Clauses and Mediation in Employment Policies, CEDR (2016). Accessed at https://www.cedr.com/about_us/modeldocs/?id=19 on November 15, 2019.

O'NEILL, Jan: UK Government announces plans for implementation of the EU ADR Directive and ODR Regulation, 2015. Accessed at http://hsfnotes.com/adr/2015/01/05/uk-government-announcesplans-for-implementation-of-the-eu-adr-directive-and-odr-regulation/ on November 15, 2019.

PODRO, Sarah - SUFF, Rachel: Mediation: an approach to resolving workplace issues, ACAS, 2013. Accessed at https://www.acas.org.uk/media/949/Mediation-An-approach-to-resolving-workplaceissues/pdf/Mediation-an-approach-to-resolving-workplace-issues.pdf on November 15, 2019.

RENWALD, Roman: Mediation in Europe: the most misunderstood method of alternative dispute resolution. World Arbitration Report, 2014, pp. 14-20. Accessed at http://www.weil.com/ /media/files/pdfs/WWAR_Newsletter_Spring2014.pdf on November 15, 2019.

Report from the Commission to the European Parliament, the Council and the European Economic and 
Debreceni Jogi Múhely 2020. (XVII.) 3-4.

Debreceni Egyetem, Állam- és Jogtudományi Kar, Debrecen

(University of Debrecen, Faculty of Law, Debrecen)

DOI 10.24169/DJM/2020/3-4/1

Social Committee on the application of Directive 2008/52/EC of the European Parliament and of the Council on certain aspects of mediation in civil and commercial matters, p. 11-12. Accessed at http://ec.europa.eu/justice/civil/files/act_part1_adopted_en.pdf on November 15, 2019.

SOLER Salvador Garrido: Insight mediation: a reflective and pedagogical model to address conflicts. Mediación insight: un modelo reflexivo y pedagógico para abordar los conflictos. Revista de Mediación, 2017, Vol. 10 Issue 10, pp. 1-9. Accessed at https://revistademediacion.com/wpcontent/uploads/2018/01/Revista20-en-e10.pdf on November 15, 2019.

SPIELMANS, John V.: Labor Disputes on Rights and on Interests. The American Economic Review, 1939, Vol. 29, No. 2, pp. 299-312 Published by: American Economic Association, Accessed at http://www.jstor.org/stable/1803627 on November 15, 2019.

STEFFEK, Felix: Mediation in the European Union: An Introduction, Cambridge, 2012, pp. 1-22., accessed at https:/ /e-justice.europa.eu/ fileDownload.do?id=b3e6a432-440d-4105-b9d5-29a8be95408f on November 15, 2019.

SUCH, Virginia Vilches - VERBEKE, Alain Laurent - MENKEL-MEADOW, Carrie: Mandatory Workplace Mediation in Advancing Workplace Mediation Through Integration of Theory and Practice. Springer, 2016, pp. 145-170. https://doi.org/10.1007/978-3-319-42842-0_9

WINSLADE, Jour - MONK, Gerald: Narrative Mediation. A new approach to conflict resolution. JosseyBass, 2000, 256 pages.

ZAHORKA Hans-Juergen, Mediation in Labour Relations: "What can be learned from the North American and EU Example? Labour Legislation and Arbitration Project, Annex 5, accessed at http://www.libertas-institut.com/de/PDF/Mediation.pdf on November 15, 2019.

ZUMETA, Zena: Styles of Mediation: Facilitative, Evaluative, and Transformative Mediation. 2018. Accessed at http:/ /www.mediate.com/articles/zumeta.cfm on November 15, 2019 